\title{
Pengaruh temperatur terhadap hasil proses pirolisis pada ban bekas pakai
}

\author{
Haris Mahmudi ${ }^{1}$, Lia Fatul Mukharomah ${ }^{2)}$ \\ ${ }^{1,2}$ Prodi Teknik Mesin, Universitas Nusantara PGRI Kediri \\ E-mail: harismahmudi@unpkediri.ac.id ${ }^{1)}$, liafatul@ymail.com ${ }^{2)}$
}

\begin{abstract}
Abstrak
Tujuan dari penelitian ini untuk mengetahui pengaruh variasi temperatur terhadap proses hasil pirolisis ban bekas dan katalis. Metode yang digunakan dalam penelitian ini adalah metode experimental nyata. Dengan temperatur sebagai variabel bebas dan nilai viskositas, densitas serta flash point sebagai variabel terikatnya. Sementara suhu kondensor dan tekanan sebagai variabel kontrol. Hasil penelitian menunjukkan adanya pengaruh temperatur terhadap hasil yang didapat. Pada suhu $350^{\circ} \mathrm{C}$ dari bahan ban bekas murni diperoleh hasil sebanyak $190 \mathrm{ml}$, dan pada suhu $350{ }^{\circ} \mathrm{C}$ dari bahan ban bekas dan katalis diperoleh hasil sebanyak $165 \mathrm{ml}$. Sedangkan untuk sifat karakteristik yang dimiliki ditinjau dari nilai viskositas, nilai viskositas terendah dari bahan ban bekas murni sebesar $350{ }^{\circ} \mathrm{C}$ sebesar $0,29 \mathrm{dPa} . \mathrm{S}$ dan dari bahan ban bekas yang dicampur dengan katalis viskositas terendah ada pada sampel $250{ }^{\circ} \mathrm{C}$ sebesar $0,29 \mathrm{dPa}$.S. sedangkan untuk nilai densitas terendah dari bahan ban bekas murni ada pada sampel $300{ }^{\circ} \mathrm{C}$ dengan nilai densitas sebesar 710 $\mathrm{Kg} / \mathrm{m} 3$ sementara untuk bahan dari ban bekas dan katalis nilai densitas terendah pada suhu $250{ }^{\circ} \mathrm{C}$ dengan nilai $780{ }^{\circ} \mathrm{C}$. Untuk nilai Flash point terendah dari bahan ban bekas murni sebesar $29^{\circ} \mathrm{C}$ dan dari bahan ban bekas dan katalis sebesar $29^{\circ} \mathrm{C}$.
\end{abstract}

Kata Kunci: pirolisis, temperatur, ban, katalis.

\begin{abstract}
The purpose of this research is to know the influence of temperature variation on the process of pyrolysis tires and catalyst. The method used in this research is the real experimental method. With temperature as independent variable and viscosity value, density and flash point as dependent variable. While the condenser temperature and pressure as a control variable. The results showed the effect of temperature on the results obtained. At a temperature of $350^{\circ} \mathrm{C}$ from pure tire material obtained as much as $190 \mathrm{ml}$, and at a temperature of $350^{\circ} \mathrm{C}$ of tire material and the catalyst obtained results as much as $165 \mathrm{ml}$. As for the characteristic properties possessed in terms of the viscosity value, the lowest viscosity value of the pure tire material of $350{ }^{\circ} \mathrm{C}$ of 0.29 dPa.S and of the used tire material mixed with the lowest viscosity catalyst is in the sample $250{ }^{\circ} \mathrm{C}$ of $0.29 \mathrm{dPa}$. S. whereas for the lowest density value of the used pure tire material is in the sample $300{ }^{\circ} \mathrm{C}$ with a density value of $710 \mathrm{~kg} / \mathrm{m} 3$ while for the material of the used tire and the lowest density catalyst at $250{ }^{\circ} \mathrm{C}$ with the value of 780 ${ }^{\circ} \mathrm{C}$. For the lowest Flash point value of pure materials used pure $29{ }^{\circ} \mathrm{C}$ and from materials used tires and catalysts of $29^{\circ} \mathrm{C}$.
\end{abstract}

Keywords: pyrolysis, temperature, tire, catalyst

D iterima 8 M aret 2018; Revisi akhir 2 M ei 2018; D iterbitkan 4 Juni 2018 


\section{PENDAHULUAN}

Penanganan limbah di lingkungan sekitar kita sangat kurang, hal ini dapat dilihat adanya tumpukan-tumpukan limbah, baik limbah rumah tangga, limbah industri dll. Limbah dapat berupa limbah cair maupun padat. Salah satu contoh limbah padat yang terdapat di lingkungan kita adalah limbah dari ban bekas pakai. Limbah ban bekas merupakan limbah padat yang berbahaya bagi lingkungan. Penumpukan limbah ban bekas dapat menjadikan sarang nyamuk dan sumber penyakit. Pembuangan ban bekas di landfill (tempat pembuangan) akan menjadikan masalah besar, karena ban bekas yang dibuang akan memenuhi ruang di tempat pembuangan tersebut. Ban mempunyai struktur komplek yang sangat sulit di daur ulang[1], ban bekas juga sangat sulit di degradasi oleh alam (Mikrobiologi).

Pemanfaatan ban bekas pakai selama ini hanya sedikit, semisal pemanfaatan menjadi hasil karya seni (bandulan, kursi), untuk tali sebagai pengikat, dan bahan bakar industri. Salah satu cara untuk menangani limbah ban bekas yang memiliki nilai tambah adalah mendegradasi secara panas (thermal) melalui proses pirolisis. Temperatur pirolisis berada pada kisaran $300 \mathrm{oC}-650 \mathrm{oC}$. Kehadiran oksigen dalam proses pirolisis akan mempengaruhi proses dekomposisi termal pada material biomassa. Kehadiran oksigen akan memicu terjadinya proses pembakarn akibat reaksi oksidasi antara material organik dan oksigen [2].

Pirolisis yang dilakukan dengan berbagai temperatur berguna untuk mengetahui produk terbaik yang bisa dihasilkan dalam proses pirolisis. Produk yang dihasilkan di analisa distribusi produknya dan sifat-sifat fisik produk cairan yang meliputi berat jenis, viskositas, dan laju pemanasannya. Berdasarkan uraian di atas, maka dilakukan penelitian mengenai Pengaruh Temperatur Terhadap Hasil Proses Pirolisis Pada Ban Bekas Pakai.

Suhu (temperatur) dalam proses ini menentukan tingkat dekomposisi material sampah, waktu tinggal dalam reaktor, dan hasil pirolisis. Laju dekomposisi dan kerusakan struktur penyusun material meningkat dengan meningkatnya temperatur reaksi pirolisis[3]. Ketika komponen yang tidak stabil secara termal, dan volatile matters pada sampah akan pecah dan menguap bersamaan dengan komponen lainnya.

Produk cair yang menguap mengandung tar dan polyaromatic hydrocarbon. Produk pirolisis umumnya terdiri dari tiga jenis, yaitu gas $(\mathrm{H} 2, \mathrm{CO}, \mathrm{CO} 2, \mathrm{H} 2 \mathrm{O}$, dan $\mathrm{CH} 4$ ), tar (pyrolitic oil), dan arang. Parameter yang berpengaruh pada kecepatan reaksi pirolisis mempunyai hubungan yang sangat kompleks, sehingga model matematis persamaan kecepatan reaksi pirolisis yang diformulasikan oleh setiap peneliti selalu menunjukkan rumusan empiris yang berbeda[4]. Produk pirolisis selain dipengruhi oleh suhu dan waktu, juga oleh laju pemanasan[5]. Pirolisis atau devolatilisasi adalah proses fraksinasi material oleh suhu. Suhu (temperatur) ini akan menentukan tingkat dekomposisi material sampah, waktu tinggal dalam reaktor, dan hasil pirolisis. Laju dekomposisi dan kerusakan struktur penyusun material meningkat dengan meningkatnya temperatur reaksi pirolisis[3]. Ketika komponen yang tidak stabil secara termal, dan volatile matters pada sampah akan pecah dan menguap bersamaan dengan komponen lainnya.

Produk cair yang menguap mengandung tar dan polyaromatic hydrocarbon. Produk pirolisis umumnya terdiri dari tiga jenis, yaitu gas $(\mathrm{H} 2, \mathrm{CO}, \mathrm{CO} 2, \mathrm{H} 2 \mathrm{O}$, dan $\mathrm{CH} 4$ ), tar (pyrolitic oil), dan arang. Parameter yang berpengaruh pada kecepatan reaksi pirolisis mempunyai hubungan yang sangat kompleks, sehingga 
model matematis persamaan kecepatan reaksi pirolisis yang diformulasikan oleh setiap peneliti selalu menunjukkan rumusan empiris yang berbeda[4]. Produk pirolisis selain dipengruhi oleh suhu dan waktu, juga oleh laju pemanasan[5].

Tujuan diadakannya penelitian ini adalah untuk mengetahui pengaruh temperatur terhadap proses pirolisis pada ban bekas murni dan ban bekas dengan katalis. Selain itu juga untuk mengetahui pengaruh temperatur terhadap karakteristik hasil produk ditinjau dari nilai viskositas, densitas dan flash pointnya. Pirolisis atau devolatilisasi adalah proses fraksinasi material oleh suhu.

\section{METODE PENELITIAN}

Dalam penelitian ini alur yang digunakan seperti pada gambar dibawah ini :

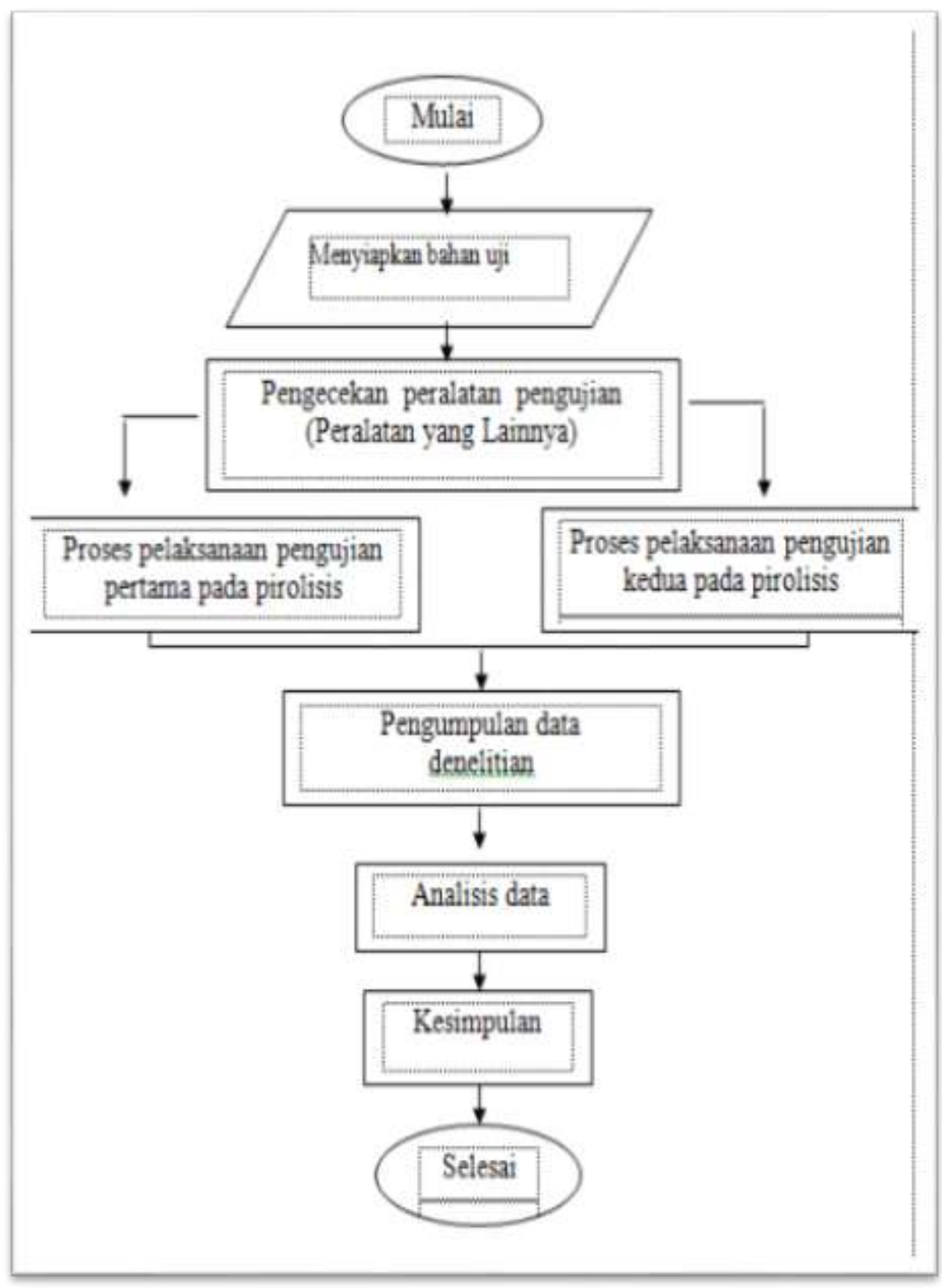

Gambar 1. Alur Penelitian 
Metode yang digunakan dalam penelitian ini adalah eksperimental nyata (true experimental research). Dengan Variabel bebasnya adalah temperatur 250oC, $300 \mathrm{oC}$ dan $350 \mathrm{oC}$ dan untuk variabel terikatnya adalah hasil cair yang ditinjau dari nilai viskositas, Densitas dan flash point. Sedangkan untuk variabel kontrolnya adalah suhu air di dalam kondensor yang dibuat konstant 26oC. Selain itu tekanan didalam reaktor 1 atmosfer. bahan yang digunakan adalah ban bekas bagian dalam yang dipotong-potong dengan ukuran $1 \mathrm{~cm}$ x $1 \mathrm{~cm}$, dan katalis zeolit dengan bentuk serbuk. Katalis yang digunakan adalah katalis Zeolit karena selain efektif juga banyak dijual dipasaran. Dengan perbandingan $10 \%$ katalis yang digunakan dalam proses perekahan. Instalasi peralatan pirolisis merupakan komponen penting untuk memperoleh hasil produk yang diinginkan. Model reaktor yang digunakan juga menentukan merata atau tidaknya pembakaran. Selain itu konstruksi kondensor yang dibuat miring juga mempengaruhi keluarnya cairan yang keluar dari pipa output. Untuk memperkecil kehilangan kalor yang berlebih, tempat pembakaran dilapisi dengan tungku. Dan kemudian akan di lapisi lagi dengan plat besi yang menutup seluruh bagian.

\section{HASIL DAN PEMBAHASAN}

Dari hasil pengujian bahan ban bekas dan ban bekas katalis diperoleh hasil cair terbanyak berdasarkan variasi temperatur, semakin tinggi temperatur hasil yang diperoleh juga semakin banyak. Selanjutnya hasil terbaik dari produk pirolisis akan di uji sifat karakteristiknya berdasarkan Viskositas, densitas dan flash pointnya.

\section{a. Pengaruh Temperatur terhadap hasil cair yang diperoleh}

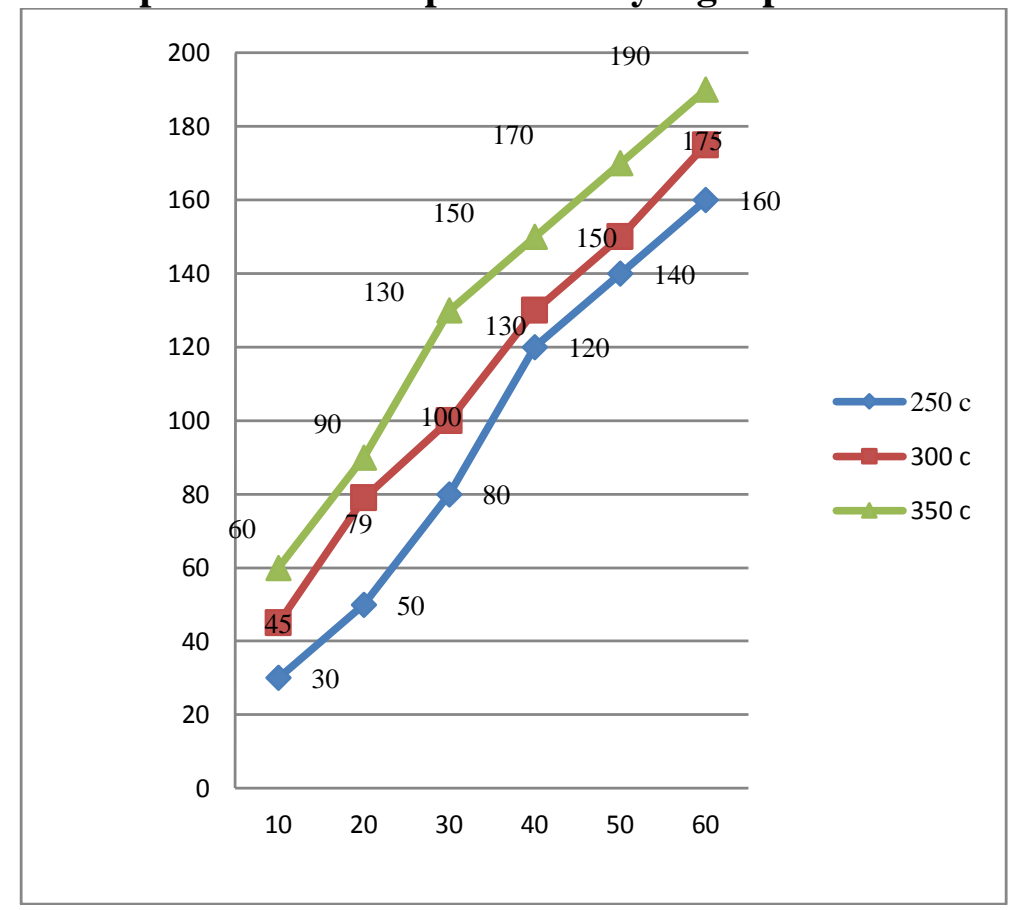

Gambar 2. Grafik perbandingan hasil cair bahan ban bekas dalam rentan waktu 60 menit

Dari grafik diatas semakin tinggi temperatur, hasil yang diperoleh juga semakin banyak. Hasil terbanyak di dapat pada suhu $350^{\circ} \mathrm{C}$ dengan waktu selama 60 menit. Hasil yang didapat sebanyak $190 \mathrm{ml}$. Sedangkan untuk grafik pengaruh temperatur 
terhadap hasil yang diperoleh dari bahan ban bekas yang dicampur dengan katalis dapat digambarkan seperti grafik dibawah ini :

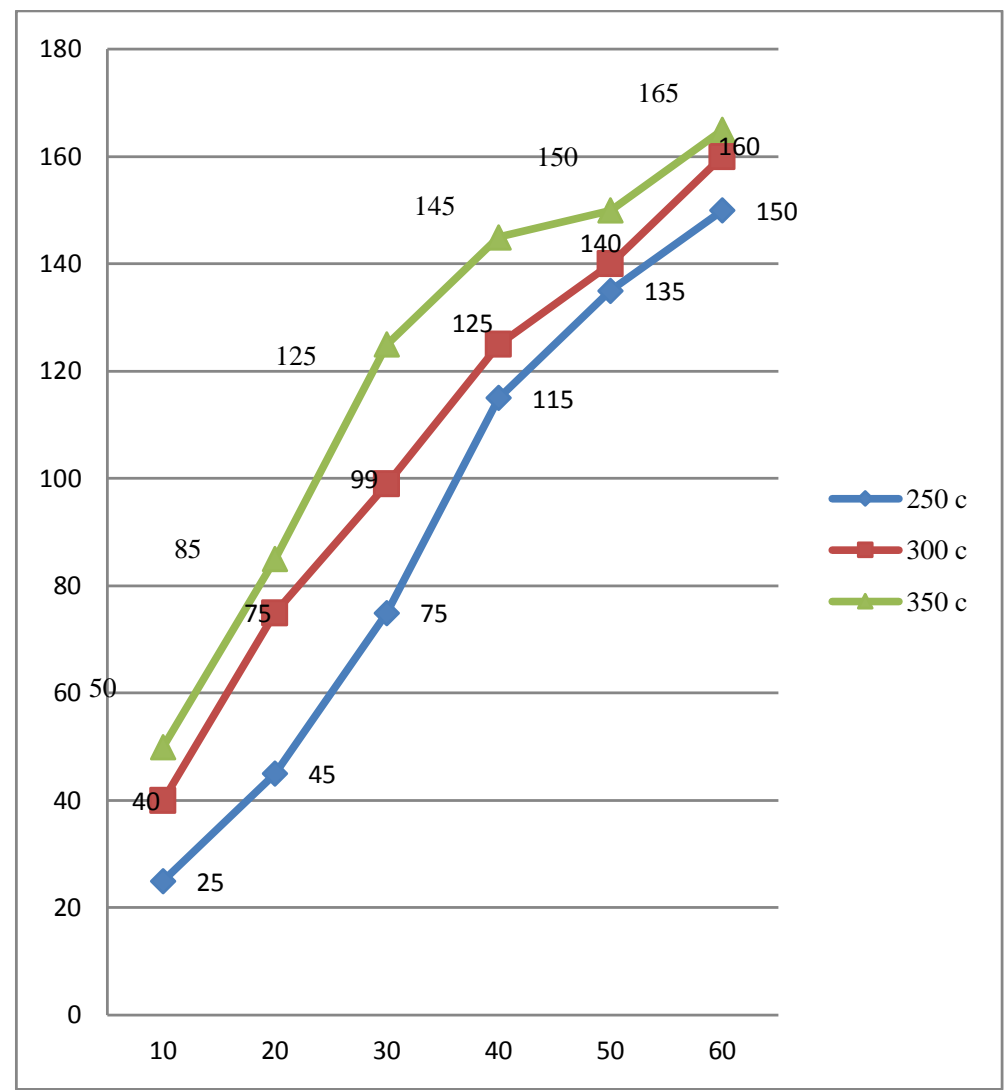

Gambar 3. Grafik perbandingan hasil cair bahan ban bekas + katalis dalam rentan waktu 60 menit

Dari gambar diatas dapat dijelaskan jika semakin tinggi temperatur hasil yang diperoleh juga semakin banyak. Dari gambar di atas hasil terbanyak terdapat pada suhu $350^{\circ} \mathrm{C}$ dengan hasil sebanyak $165 \mathrm{ml}$.

Perbandingan hasil cair dari bahan ban bekas dan ban bekas katalis cukup signifikan. Bahan yang menggunakan campuran katalis memiliki hasil cair yang lebih sedikit dibandingkan dengan bahan dari ban bekas murni. Hal ini disebabkan karena bahan yang menggunakan katalis rantai panjang karbonnya akan dipecah oleh katalis sehingga hasilnya lebih banyak ke fraksi gas dan fraksi cairnya lebih sedikit.

\section{b. Pengaruh Temperatur terhadap Viskositas}

Temperatur optimum saat pemanasan berpengaruh terhadap sifat karakteristiknya. Pengaruh temperatur terhadap viskositas dapat dilihat pada grafik di bawah ini : 


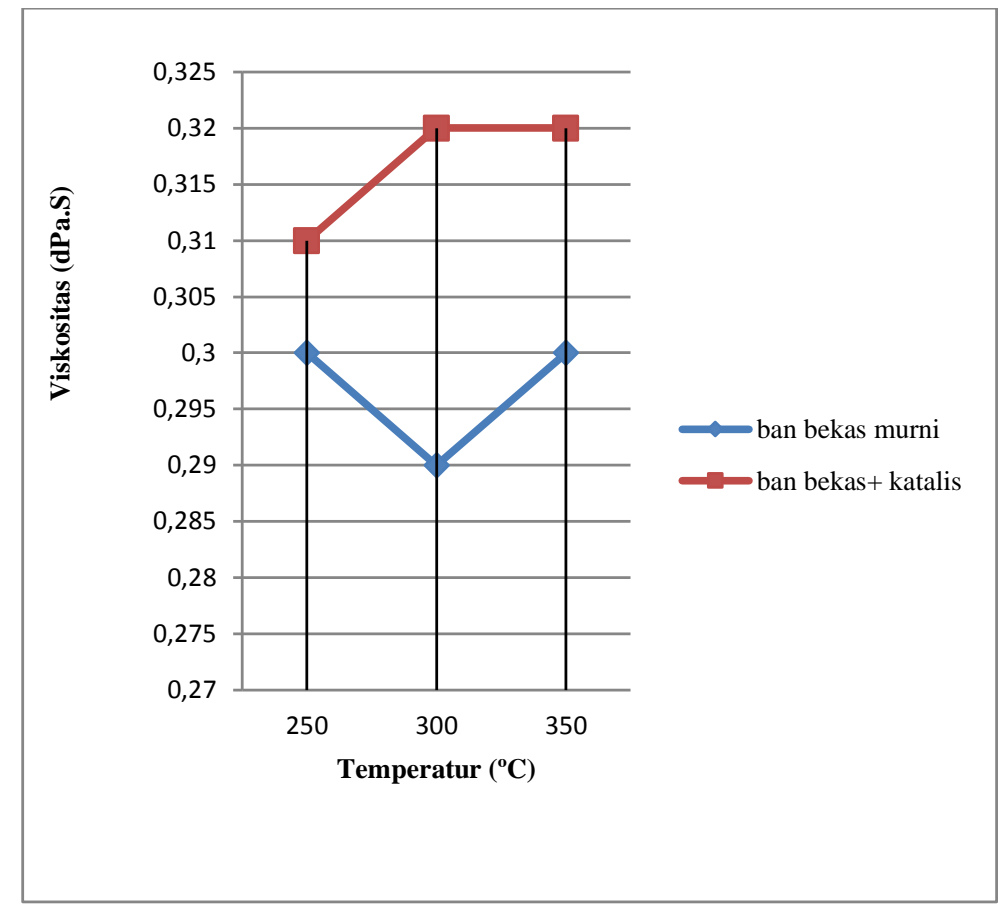

Gambar 4. Pengaruh temperatur terhadap viskositas

Semakin rendah nilai viskositas yang dimiliki cairan maka cairan tersebut semakin encer. Viskositas dari bahan ban bekas murni memiliki nilai terendah sebesar $0.29 \mathrm{dPa} . \mathrm{S}$ pada sampel suhu $300^{\circ} \mathrm{C}$. Sedangkan pada ban bekas yang ditambah dengan katalis nilai viskositas terendah sebesar $0.31 \mathrm{dPa} . \mathrm{S}$ pada sambel dengan suhu $250^{\circ} \mathrm{C}$.

\section{c. Pengaruh Temperatur terhadap Densitas}

Pengaruh perubahan temperatur terhadap densitas (massa jenis) dari bahan ban bekas pakai murni dan ban bekas pakai + katalis tersaji dalam grafik yang ditunjukkan pada gambar 6 berikut.

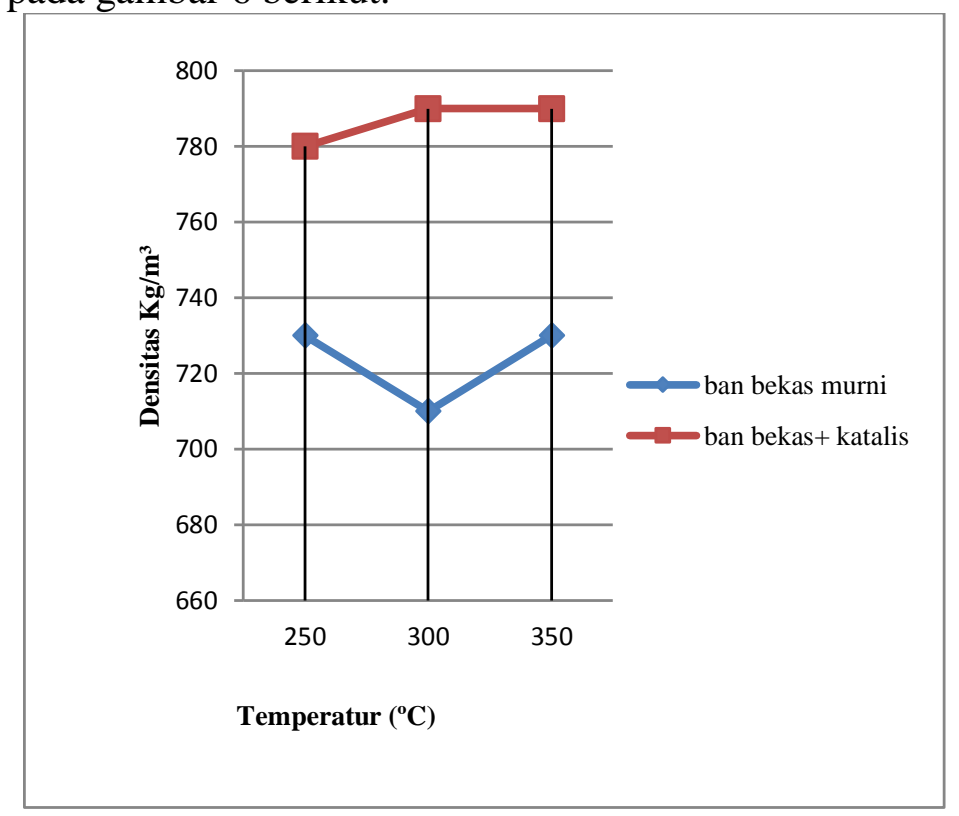

Gambar 5. Pengaruh temperatur terhadap densitas 
Densitas dari bahan ban bekas murni memiliki nilai terendah sebesar $710 \mathrm{Kg} / \mathrm{m} 3$ pada sampel suhu $300^{\circ} \mathrm{C}$. Sedangkan pada ban bekas yang ditambah dengan katalis nilai densitas terendah sebesar $780 \mathrm{Kg} / \mathrm{m} 3$ pada sambel dengan suhu $250^{\circ} \mathrm{C}$.

\section{d. Pengaruh Temperatur terhadap Flash point}

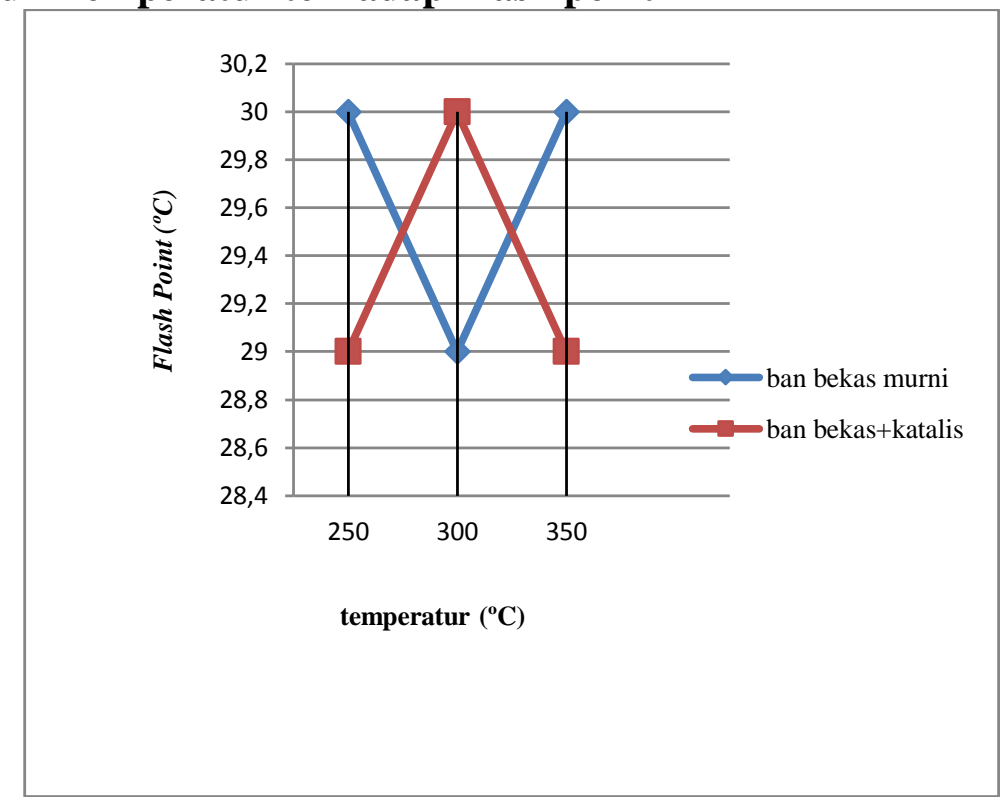

Gambar 6. Pengaruh temperatur terhadap Flash point

Flash point dari bahan ban bekas murni memiliki nilai terendah sebesar $29^{\circ} \mathrm{C}$ pada sampel suhu $300^{\circ} \mathrm{C}$. Sedangkan pada ban bekas yang ditambah dengan katalis nilai densitas terendah sebesar $29^{\circ} \mathrm{C}$ pada sambel dengan suhu $250^{\circ} \mathrm{C}$.

Dari ketiga sifat karakteristik kedua bahan memiliki suhu optimum yang berbeda.Sifat karakteristik yang dimiliki bahan ban bekas murni memiliki nilai viskositas, densitas dan flash point terendah pada suhu $300^{\circ} \mathrm{C}$. Dalam hal ini kualitas cairan juga memiliki kualitas terbaik dengan warna kuning jernih. Sedangkan pada sampel ban bekas dan katalis suhu optimumnya lebih rendah yaitu $250^{\circ} \mathrm{C}$. Hal ini karena katalis berfungsi mempercepat reaksi sehingga suhu optimumnya lebih rendah. Akan tetapi kualitas hasil dengan menggunakan katalis masih lebih baik bahan ban bekas murni.

\section{KESIMPULAN}

Dari hasil analsis yang telah dilakukan, maka kesimpulan sebagai berikut :

a. Hasil terbanyak produk pirolisis (cair) dari bahan ban bekas murni terdapat pada suhu $350^{\circ} \mathrm{C}$ sebanyak $190 \mathrm{ml}$ dan pada dan ban bekas dengan katalis hasil terbanyak pada suhu tertinggi yaitu $350^{\circ} \mathrm{C}$ sebanyak $165 \mathrm{ml}$.

b. Sifat karakteristik yang dimiliki dari variasi temperatur berbeda-beda, adapun nilainya sebagai berikut :

c. Nilai Viskositas terendah terdapat pada suhu $300^{\circ} \mathrm{C}$ dengan sampel ban bekas murni yaitu 0,29 dPa.S sedangkan untuk sampel ban bekas yang dicampur dengan katalis viskositas terendah terdapat pada suhu $250^{\circ} \mathrm{C}$ dengan nilai 0,29 d.Pa.S

d. Nilai Densitas terendah terdapat pada suhu $300^{\circ} \mathrm{C}$ dengan sampel ban bekas 
murni yaitu $710 \mathrm{~kg} / \mathrm{m} 3$, sedangkan untuk sampel ban bekas yang dicampur dengan katalis densitas terendah berada pada suhu $250^{\circ} \mathrm{C}$ dengan nilai 780 $\mathrm{Kg} / \mathrm{m} 3$.

e. Nilai Flash point terendah terdapat pada suhu $300^{\circ} \mathrm{C}$ dengan sampel ban bekas murni yaitu $29^{\circ} \mathrm{C}$ sedangkan untuk sampel ban bekas yang dicampur dengan katalis flash point terendah berada pada suhu $250^{\circ} \mathrm{C}$ dengan nilai $29^{\circ} \mathrm{C}$.

\section{DAFTAR PUSTAKA}

[1] Zabaniotou, A . A and G. Stravropoulus. 2003. Pyrolisis of Used Automobile Tires and Residual Char Utilization. Journal of analitical and applied pyrolysis. $70: 711-722$

[2] Karlsson, J. 2013. Evaluation of Torrefaction Pilot Plant in Klintehamn. Department of Chemical Engineering. Lund University: Sweden

[3] Bridgeman, T.G, et all. 2008. Torrefaction of reed canary grass, wheat straw and willow to enhance solid fuel qualities and combustion properties. Fuel.V, 87: P. 844-856.

[4] Trianna N.,W. dan Rochimoellah,M. 2002. Model Kinetika Reaksi Heterogen pada Pirolisis, Prosiding Rekayasa Kimia dan Proses. ISSN 1411-4216, B-16, UNDIP.

[5] Rudiasono, dkk. 2007. Pembuatan dan Uji Aktivasi Katalis NiMo/Z Pada Reaksi Hidro Rengkah Fraksi Sampah Plastik menjadi Fraksi Bensin. Berkala MIPA, 17 (2), Mei 2007. 